\title{
A question of adaptability: Climate and habitat change lower trait diversity in butterfly communities in south-western Germany
}

\author{
Katharina J. FILZ ${ }^{1}$, Martin WIEMERS², Anne HERRIG ${ }^{1}$, Matthias WEITZEL ${ }^{3}$ and Thomas SCHMiTT $^{1}$ \\ ${ }^{1}$ Biogeography Department, Faculty of Geography/Geosciences, Trier University, Universitätsring 15, 54296 Trier, Germany; \\ e-mails: kfilz@yahoo.de; s6anherr@uni-trier.de; thsh@uni-trier.de \\ ${ }^{2}$ UFZ, Helmholtz Centre for Environmental Research, Theodor-Lieser-Str. 4, 06120 Halle, Germany; \\ e-mail: martin.wiemers@ufz.de \\ ${ }^{3}$ Graf-Reginar-Straße 43, 54294 Trier, Germany; e-mail: matthias-weitzel@web.de
}

Key words. Lepidoptera, species decline, community composition change, habitat specialisation, functional groups, community temperature index, fallows, south-western Germany

\begin{abstract}
Invertebrate diversity has rapidly declined throughout Europe during the last century. Various reasons for this decrease have been proposed including human induced factors like climate change. Temperature changes alter distributions and occurrences of butterflies by determining habitat conditions at different scales. We evaluated changes in the composition of butterfly communities recorded at nine areas of fallow ground in south-western Germany in 1973, 1986, 2010 and 2012 using Pollard's transect technique. To demonstrate the importance of climatic changes in affecting butterfly communities, we calculated the community temperature index (CTI) for each butterfly community in each year. Although they increased slightly, the CTI-values did not match the temperature trends recorded in the study region. However, the reduction in the standard deviations of the CTIs over time is reflected in the marked loss of cold- and warm-adapted species due to their inability to cope with temperature and land-use induced habitat changes. Results of our butterfly surveys indicate a marked decline in species richness and striking changes in the composition of the butterfly communities studied. This trend was most pronounced for habitat specialists, thus mirroring a depletion in trait diversity. Our results indicate that, in the course of large-scale anthropogenic changes, habitat degradation at smaller scales will continuously lead to the replacement of habitat specialists by ubiquitous species.
\end{abstract}

\section{INTRODUCTION}

Many studies over the past few decades have documented a broad-scale decline in the number of species. Various reasons have been proposed for this decline and in general there is considerable concern about the future of biodiversity (Sala et al., 2000; Gaston \& Fuller, 2007; Beaumont et al., 2011; Dawson et al., 2011). Climate change and landscape changes leading to habitat destruction and fragmentation are identified as major threats to biodiversity in the 21 st century (Thomas et al., 2004a; Dover \& Settele, 2009). Therefore, the accurate identification of such emerging threats is crucial for developing appropriate in situ management and conservation strategies (Mantyka-Pringle et al., 2012).

Butterflies are known to respond quickly to a number of environmental parameters and therefore they are used as an umbrella group in insect conservation (Rákosy \& Schmitt, 2011). The ongoing decline in the abundance of many species of butterfly species throughout Europe (León-Cortés et al., 2000; Maes \& Van Dyck, 2001; Van Swaay et al., 2011) highlights the need to identify environmental factors influencing species diversity and the habitats that need conserving.

Insect diversity and butterfly species richness are closely related to certain habitat characteristics. In agricultural dominated landscapes, human activities have created a characteristic mosaic of open habitats, forests and floodplains (Schmitt \& Rákosy, 2007) with suitable habitats for a multitude of species. However, the abandonment and replacement of traditional farming and systems of landscape management, which ensured their survival for hundreds of years, is particularly deleterious for these taxa (Warren, 1997; Wenzel et al., 2006; Schmitt \& Rákosy, 2007). Two frequently observed biological changes following anthropogenic activities or climate changes are species loss and biotic homogenization over time (Wenzel et al., 2006; Gillette et al., 2012). In addition to habitat loss, reduction in habitat size and fragmentation, as well as changes in micro- and meso-climatic conditions within habitats are also major threats to diversity. The degree to which habitats become increasingly unsuitable for butterflies due to changing micro-climatic conditions is still under debate. In contrast to broad-scale climatic effects on biodiversity, small-scale effects influencing habitat associations are poorly understood. A better understanding of these small-scale effects would fundamentally improve the ecological understanding of natural communities, especially those harbouring specialized species with narrow physical tolerances. Moreover, it would enhance the development of conservation efforts for maintaining species diversity under climate change.

In Europe, semi-natural grasslands (e.g. old fallow grounds) are currently considered to be important habitats in cultivated landscapes (Van Swaay, 2002). These habitats are usually characterised by higher plant diversity and 


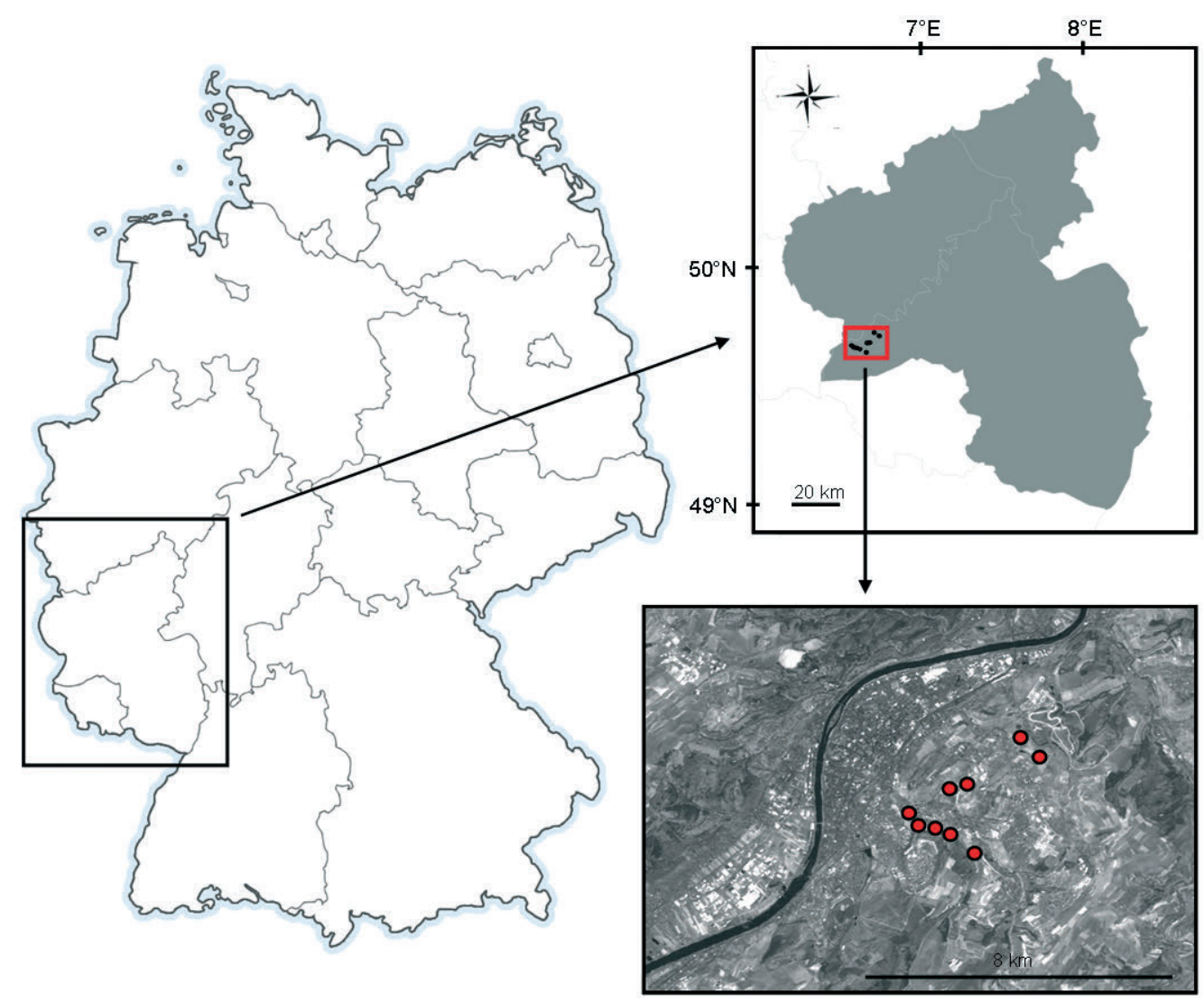

Fig. 1. Location of the study sites in the Rhineland-Palatinate, Germany. Circles indicate the location of the transects near the city of Trier (left: Tiergarten I, Tiergarten II, Tiergarten III, Hill, Kernscheid; centre: Brettenbach I, Brettenbach II; right: Avelertal II, Avelertal III).

more favourable (often warmer) climatic conditions than the surroundings. Hence, they provide retreats for many taxa and host a high diversity of plants and animals, which differ from those inhabiting intensively cultivated farmland. They are particularly valuable for the conservation of insect diversity (Wenzel et al., 2006). However, conservation activities may be misleading as little is known about the within-habitat dynamics influencing local species diversity and composition of communities.

In the present study, we compare contemporary (2010, 2012) butterfly communities to historical $(1973,1986)$ assemblages in vineyard fallows in south-western Germany. Over the time period of this study, temperature in this region has increased by approximately one degree Celsius, but with considerable variations in temperature from year to year. To demonstrate the importance of climatic changes in affecting butterfly communities, we calculated the community temperature index (CTI) for each butterfly community in each year. The CTI is acknowledged to be a good indicator of the effects of climate change on biodiversity by the pan-European framework supporting the Convention on Biological Diversity (CBD). Based on species specific temperature indices, it reflects the relative composition of heat-loving versus cold-adapted species in local communities of a given taxonomic group (Devictor et al., 2012). Due to the increase in temperature it is expected that there will be an increase in CTI values, which will reflect shifts in com- munities towards more heat-loving species. For butterfly species, CTI-values show a strong correlation with the two-year moving temperature average so annual variations might be more important than the overall trend (Wiemers et al.; 2012).

In addition to a rich fauna, it is acknowledged that there is a high functional diversity in vineyard fallows. We analyzed how butterflies differing in distribution patterns, dispersal abilities and habitat specialisation have responded specifically to recent climate change expecting a decrease in species richness, and especially in functional diversity. The loss of less thermophilic butterflies or range contractions of those species that are at the edge of their distribution in Germany might lead to depleted communities. Although it might not be possible to generalize from the results of this case study it might stimulate a discussion about small-scale effects on the composition of local communities and its implications for species conservation.

\section{MATERIAL AND METHODS}

\section{Study region}

This study was carried out in the vicinity of Trier, which is located in south-western Germany near to the border with France and Luxembourg (see Fig. 1). The area is characterized by a long tradition of human settlement and anthropogenic landuse. Since Roman times, landscape characteristics were transformed leading to an increase in open habitats. The growing 
structural diversity in habitats encompassing residential areas, arable fields, vineyards, meadows, forests and flood plains fostered species diversity. Today, a multitude of natural and seminatural habitats provide retreats for many rare and endangered species.

However, changes in climatic conditions and land-use patterns during the $20^{\text {th }}$ century have had severe negative effects on the quantity and quality of these habitats. The intensification of farming, anthropogenic loading of nutrients, the failure of extensive management and a changing climate have resulted in the loss and fragmentation of certain habitats, potentially leading to a decline in species diversity.

\section{Study sites}

Nine xerothermic vineyard and grassland fallows were selected for the butterfly surveys. Old fallows are assumed to be considerably species rich and important retreats for rare and endangered species in cultivated landscapes. All patches were surrounded by intensively cultivated farmland (mostly vineyards), hay meadows and areas of housing and hence highly fragmented. Minimum distance between patches was $200 \mathrm{~m}$ (Brettenbach I; Brettenbach II). In the other cases, geographic distances were on average $1.6 \mathrm{~km}$. A spatial autocorrelation among patches was excluded as the turnover rates between all study patches revealed there was no influence of spatial distance on species composition (Kruskal-Wallis-test $\mathrm{p}_{\text {same }}=0.88$, see Appendix 1).

All study sites were structurally young fallows in 1973 and ceased to be used for agriculture purposes more than fifty years ago. The vegetation was dominated by perennial bunch grasses, a variety of thermophilic flowering herbaceous plants and a few interspersed hedges composed of Rosa ssp., Rubus ssp., Cytisus scoparius and some Crataegus monogyna. Height of the vegetation varied throughout the year, but on average did not exceed $80 \mathrm{~cm}$. With the exception of one transect (Hill), geological conditions and microclimatic factors prevented the vegetational succession to secondary forest. The vegetal characteristics of three fallows have been maintained by occasional extensive sheep pasturing once or twice a year, whereas six fallows were abandoned.

The vineyard fallows studied stretched across a total area of 7.34 ha. Patch size varied between 0.38 ha (Kernscheid) and 1.48 ha (Avelertal III). In 1973, one transect of varying length was established per patch. These transects were re-established and re-investigated in 1986, 2010 and 2012 in cooperation with the initial observer (M. Weitzel). In 2010 and 2012 butterfly surveys were carried out at all study sites whereas in 1986 only three transects were reinvestigated.

\section{Data acquisition}

We used the method developed for the UK Butterfly Monitoring Scheme (Pollard \& Yates, 1993) for determining species presence/absence and abundance from the results of field surveys carried out at nine locations in south-western Germany. Standardized butterfly counts were made along fixed transects. Each butterfly seen $5 \mathrm{~m}$ ahead and $2.5 \mathrm{~m}$ on each side of the observer was counted. Individuals seen were either counted or captured with a butterfly net for closer determination. Transect counts were performed several times throughout the year during the peak flight period of the species of butterfly known to occur in this area in order to avoid misinterpretation of extreme abundances or zero abundances that can arise from single surveys and variations in numbers of generations in certain species of butterfly. Each transect was visited every ten days (if weather conditions permitted) from April to October for a period of time dependent on its length. These counts were made between 10:00 am and 5:00 pm when weather conditions were suitable (Pollard \& Yates, 1993; Settele et al., 1999), i.e. temperature above $17^{\circ} \mathrm{C}$, wind speed less than six on the Beaufort scale and not raining (Van Swaay et al., 2008). Variations due to weather and time of day were counterbalanced by randomising the butterfly surveys. The results of each transect walk was kept along with a description of the weather conditions and recent management activities.

Field work was similar in all the years of this study. Bias in data acquisition was minimized by conducting butterfly surveys at the same time each year using congruent transects as well as identical field methods. The number of transect walks was similar each year and varied between 109 in 2010 and 96 in 2012. Only in 1986 there was a smaller number of walks, which reflects the smaller number of sites surveyed in that year (i.e. three transects).

\section{Classification of butterflies}

The butterflies recorded were classified into functional groups defined by their dispersal behaviour, habitat requirements, larval food plant specialisation and global distribution patterns.

We used the classification of Bink (1992) for the analysis of dispersal abilities. However, for easier manageability, the nine dispersal classes were condensed into three new ones: poor dispersers (class 1-3), medium dispersers (class 4-6) and good dispersers (class 7-9). For general habitat requirements, we used the classification of Reinhardt \& Thust (1988) to distinguish between ubiquitous, mesophilic, hygrophilic and xerothermophilic species. In terms of food plant use caterpillars were classified as monophagous (only one plant genus), oligophagous (only plants of one family) and polyphagous (several plant families) (Ebert \& Rennwald, 1991). Distribution patterns were obtained from Kudrna et al. (2011). We classified a species of butterfly as Mediterranean if its distribution area includes southern Iberia, southern Italy or Greece. The distribution areas of continental species usually exclude these regions and do not reach the lowland areas along the coast of the Atlantic or the British Isles. A species was classified as Mediterraneancontinental if its distribution area includes at least one of the areas typical for Mediterranean species, but also extends into continental parts of Eurasia.

Leptidea sinapis, L. reali and L. juvernica were treated as a sibling species complex in this study because the splitting of this complex into these two species occurred after 1973. Nomenclature of butterflies follows Gaedike \& Heinicke (1999).

\section{Statistical analysis}

We constructed a data matrix for each year containing the number of individuals of each species observed. To exclude outliers due to unsuitable conditions (e.g. weather), the mean number of each species observed each month was expressed in terms of a $1000 \mathrm{~m}$ transect length and summed to give the annual value. Differences in species composition between years and sites were evaluated using univariate und multivariate statistics. Tests among study sites and years were done using Kruskal-Wallis Tests and Cochran-Q-tests.

Turnover rates were determined in order to identify changes in the communities between years. This rate was calculated as the number of species recorded in one of the years divided by the total number of species observed in both years. As similarity coefficient we calculated Jaccard's index, which was obtained by dividing the number of species recorded in a particular patch by the number of species recorded in each patch. Moreover, a hierarchical cluster analyses was conducted based on presenceabsence data recorded for each transect to test for similarities between the butterfly assemblages in different years. All statis- 


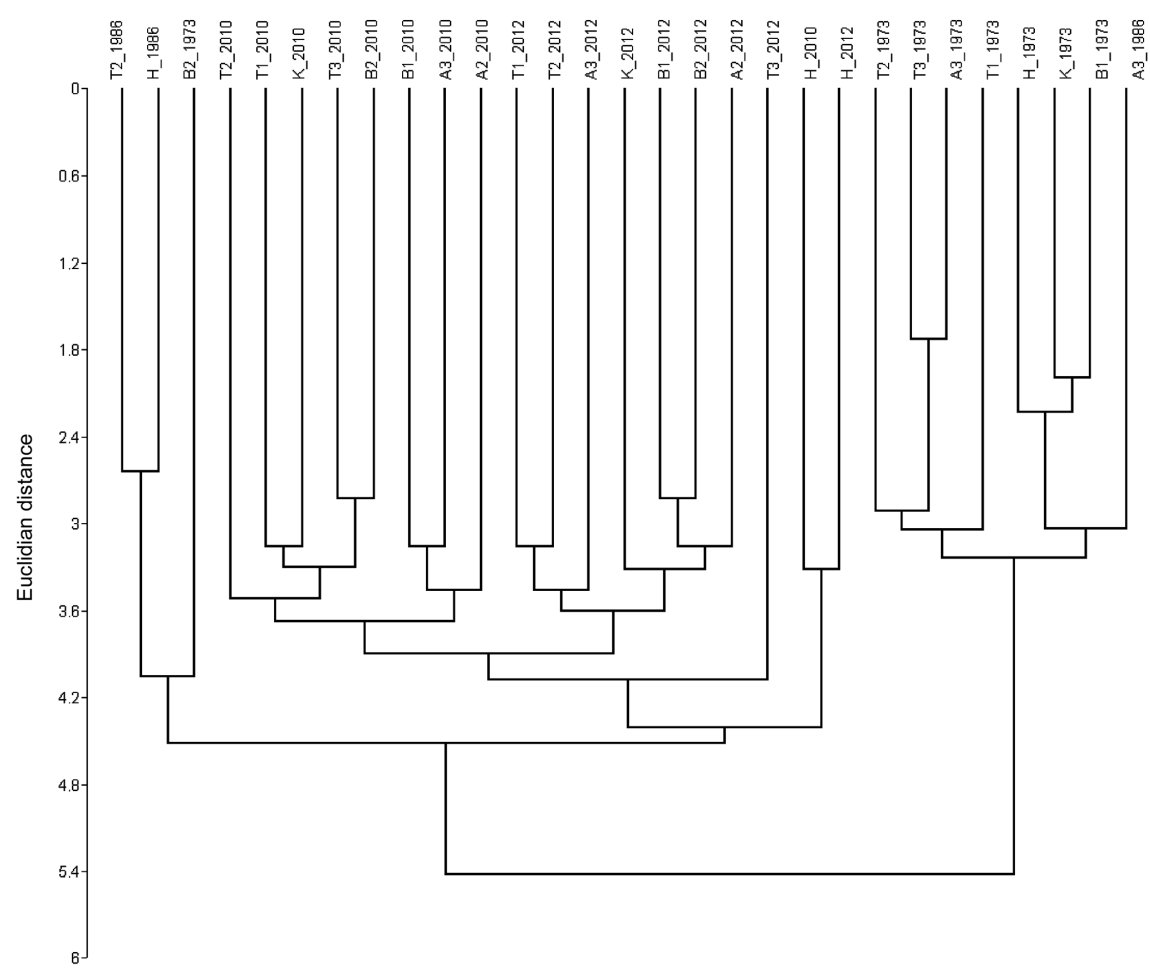

Fig. 2. Results of the cluster analysis based on presence-absence data, which indicates the degree of similarity between the butterfly assemblages recorded along the transects in the years 1973, 1986, 2010 and 2012 (T1 - Tiergarten I, T2 - Tiergarten II, T3 Tiergarten III, H - Hill, K - Kernscheid, B1 - Brettenbach I, B2 - Brettenbach II, A2 - Avelertal II, A3 - Avelertal III).

tics were calculated using PAST 2.17b (O. Hammer, Geological Museum of Copenhagen), SPSS 15.0 and Microsoft Excel 2010.

\section{Community temperature indices (CTI)}

For each butterfly species, a Species Temperature Index (STI) was obtained from the European distribution data of Kudrna (2002) and the climate data used by Settele et al. (2008). The STI is the long-term average temperature experienced by individuals of that species over its entire range. Species that occur predominantly in the warmer areas of Europe (e.g. Mediterranean species) have higher STIs than more northerly distributed species. For each patch studied and every year, a Community Temperature Index (CTI) was calculated as the average of the STIs of all the species present in the assemblage. A higher CTI would thus reflect a higher proportion of species with high STIs.

\section{RESULTS}

\section{Species decline}

The field surveys in 1973, 1986, 2010 and 2012 documented significantly different numbers of species and individuals in all the patches (Kruskal-Wallis-Test, $\mathrm{p}_{\text {same }}<$ 0.01 ) and remarkable changes in community composition. In 2010,21 species, i.e. $36 \%$ of the species present in 1973 , were not recorded. In contrast, the numbers of species were only slightly different in 2010 and 2012. The number of species that were newly recorded each year was low ranging between three in 2010 and four in 2012. In all cases, the number of newly recorded species did not compensate for the loss of species.

Turnover rates were high in all the patches ranging from 15\% (2010-2012) to 33\% (1973-2012). Moreover, the average Jaccard's similarity index was 0.61 , which indicates that community composition changed over time.
Grazing did not appear to have an effect on species richness and community composition as there was no difference between grazed and non grazed patches.

Cluster analysis based on presence-absence data revealed marked changes in community composition between the early and later years of this study (Fig. 2). There was a considerably higher degree of similarity in the community composition in the years 2010 and 2012 and the composition in those two years differed considerably from that in 1973. Records for 1986 had an intermediate value as the records for one transect were very similar to those recorded in 1973, whereas for the other two transects they were similar to those recorded in 2010 and 2012.

Presence-absence data for all species including the number of transects along which particular species were recorded in each year is given in Table 1.

\section{Changes in community composition}

All functional groups were again recorded in 1986, 2010 and 2012. However, declines in numbers of species were accompanied by significant changes in the composition of each functional group (Fig. 3). Most of the species recorded in 1973 were mesophilic, monophagous and/or sedentary. In 2010/12, the majority of the species was mesophilic, polyphagous and/or mobile. The most marked decreases were observed for butterfly species that were highly host specific $(\mathrm{p}<0.05)$, i.e. in $2010 / 12$ a significantly higher proportion of generalist species was recorded than in 1973. Consequently, there was also a considerable decrease in numbers of sedentary species. The numbers of species of butterflies with poor dispersal 
TABLE 1. Presence-absence data for all butterfly species recorded in vineyard fallows in south-western Germany. Numbers indicate the number of study sites with a particular species present in a particular year, and the functional traits of that species are listed in the final column (D1 - sedentary, D2 - medium, D3 - migrant; P1 - monophagous, P2 - oligophagous, P3 - polyphagous; H1 - xerothermophilic, H2 - mesophilic, H3 - hygrophilic, H4 - ubiquitous; A1 - Mediterranean, A2 - continental, A3 - continental-Mediterranean, A4 - migrant). Note that the number of transects surveyed varied between years: 1973 - eight; 1986 - three; 2010/12 - nine.

\begin{tabular}{|c|c|c|c|c|c|}
\hline & 1973 & 1986 & 2010 & 2012 & Traits \\
\hline \multicolumn{6}{|l|}{ HESPERIDAE } \\
\hline Erynnis tages (L., 1758) & 7 & 3 & 0 & 0 & D1 P2 H1 A1 \\
\hline Carcharodus alceae (Esp., 1780) & 7 & 3 & 0 & 1 & D2 P2 H1 A1 \\
\hline Spialia sertorius (Hoff., 1804) & 6 & 0 & 0 & 0 & D1 P1 H1 A1 \\
\hline Pyrgus malvae (L., 1758) & 8 & 3 & 6 & 6 & D1 P2 H2 A1 \\
\hline Carterocephalus palaemon (Pal., 1771) & 3 & 0 & 0 & 0 & D1 P2 H2 A2 \\
\hline Thymelicus lineola $(\mathrm{O} ., 1808)$ & 8 & 3 & 6 & 8 & D2 P2 H2 A2 \\
\hline Thymelicus sylvestris (Poda, 1761) & 5 & 3 & 7 & 8 & D1 P2 H2 A1 \\
\hline Ochlodes sylvanus (Esp., 1778) & 8 & 3 & 4 & 1 & D2 P3 H4 A1 \\
\hline \multicolumn{6}{|l|}{ PAPILIONIDAE } \\
\hline Papilio machaon L., 1758 & 8 & 3 & 7 & 3 & D2 P3 H2 A1 \\
\hline \multicolumn{6}{|l|}{ PIERIDAE } \\
\hline Leptidea sinapis (L., 1758) / reali Reiss., 1989 / juvernica Williams, 1946 & 8 & 3 & 9 & 6 & D2 P2 H2 A1 \\
\hline Anthocharis cardamines (L., 1758) & 8 & 3 & 9 & 2 & D2 P2 H2 A3 \\
\hline Aporia crataegi (L., 1758) & 6 & 1 & 6 & 0 & D2 P2 H2 A1 \\
\hline Pieris brassicae (L., 1758) & 8 & 3 & 4 & 4 & D3 P3 H4 A1 \\
\hline Pieris rapae (L., 1758) & 8 & 3 & 9 & 9 & D2 P3 H4 A1 \\
\hline Pieris napi (L., 1758) & 8 & 3 & 7 & 9 & D2 P3 H4 A1 \\
\hline Colias croceus (Fourc., 1785) & 2 & 2 & 0 & 0 & D3 P2 H4 A4 \\
\hline Colias hyale (L., 1758) & 8 & 3 & 6 & 7 & $\mathrm{D} 2 \mathrm{P} 2 \mathrm{H} 2 \mathrm{~A} 2$ \\
\hline Gonepteryx rhamni (L., 1758) & 8 & 3 & 8 & 4 & D2 P2 H2 A1 \\
\hline \multicolumn{6}{|l|}{ LYCAENIDAE } \\
\hline Hamearis lucina (L., 1758) & 5 & 1 & 0 & 0 & D1 P1 H2 A2 \\
\hline Lycaena phlaeas (L., 1761) & 8 & 3 & 6 & 4 & D2 P1 H2 A1 \\
\hline Lycaena dispar (Haw., 1803) & 0 & 0 & 1 & 1 & D2 P1 H3 A2 \\
\hline Lycaena tityrus (Poda, 1761) & 8 & 2 & 3 & 3 & D1 P1 H2 A3 \\
\hline Lycaena hippothoe (L., 1761) & 1 & 0 & 0 & 0 & D1 P1 H3 A2 \\
\hline Thecla betulae (L., 1758) & 8 & 1 & 1 & 1 & D1 P1 H2 A2 \\
\hline Neozephyrus quercus (L., 1758) & 3 & 1 & 0 & 0 & D1 P1 H1 A3 \\
\hline Callophrys rubi (L., 1758) & 8 & 3 & 5 & 1 & D2 P3 H2 A1 \\
\hline Satyrium w-album (Knoch, 1782) & 3 & 0 & 0 & 0 & D1 P1 H2 A2 \\
\hline Satyrium pruni (L., 1758) & 8 & 3 & 0 & 0 & D1 P1 H1 A2 \\
\hline Cupido minimus (Fues., 1775) & 4 & 1 & 0 & 0 & D1 P1 H1 A3 \\
\hline Cupido argiades (Pallas, 1771) & 0 & 0 & 3 & 7 & D2 P2 H1 A2 \\
\hline Celastrina argiolus (L., 1758) & 8 & 3 & 1 & 2 & D2 P3 H2 A3 \\
\hline Aricia agestis ([Den. \& Schiff.], 1775) & 0 & 2 & 8 & 5 & D2 P3 H1 A1 \\
\hline Polyommatus semiargus (Rott., 1775) & 7 & 2 & 7 & 4 & D2 P1 H2 A1 \\
\hline Polyommatus icarus (Rott., 1775) & 8 & 3 & 8 & 5 & $\mathrm{D} 2 \mathrm{P} 2 \mathrm{H} 4 \mathrm{~A} 1$ \\
\hline Polyommatus coridon (Poda, 1761) & 4 & 0 & 0 & 0 & D2 P1 H1 A1 \\
\hline \multicolumn{6}{|l|}{ Nymphalidae } \\
\hline Argynnis paphia (L., 1758) & 5 & 1 & 1 & 0 & D2 P1 H2 A3 \\
\hline Argynnis aglaja (L., 1758) & 7 & 1 & 4 & 0 & D1 P1 H2 A1 \\
\hline Argynnis adippe ([Den. \& Schiff.], 1775) & 0 & 1 & 0 & 0 & D2 P1 H2 A3 \\
\hline Issoria lathonia (L., 1758) & 4 & 1 & 7 & 5 & D2 P1 H2 A1 \\
\hline Brentis ino (Rott., 1775) & 2 & 0 & 0 & 0 & D1 P2 H3 A2 \\
\hline Brenthis daphne (Berg., 1780) & 0 & 0 & 0 & 1 & D1 P1 H1 A1 \\
\hline Boloria selene ([Den. \& Schiff.], 1775) & 8 & 1 & 0 & 0 & D1 P1 H3 A2 \\
\hline Boloria dia (L., 1767) & 0 & 1 & 0 & 2 & D2 P1 H1 A2 \\
\hline Vanessa atalanta (L., 1758) & 8 & 1 & 6 & 8 & D3 P1 H4 A4 \\
\hline Vanessa cardui (L., 1758) & 8 & 1 & 1 & 2 & D3 P3 H4 A4 \\
\hline Inachis io (L., 1758) & 8 & 1 & 9 & 3 & D2 P3 H4 A3 \\
\hline Aglais urticae (L., 1758) & 8 & 1 & 8 & 5 & D2 P1 H4 A1 \\
\hline Polygonia c-album (L., 1758) & 8 & 1 & 5 & 5 & D2 P3 H2 A1 \\
\hline Araschnia levana (L., 1758) & 8 & 1 & 6 & 4 & D2 P1 H2 A2 \\
\hline Nymphalis polychloros (L., 1758) & 3 & 1 & 0 & 0 & D2 P3 H2 A3 \\
\hline Melitaea cinxia $(\mathrm{L} ., 1758)$ & 3 & 0 & 2 & 1 & D1 P1 H2 A3 \\
\hline Melitea diamina (Lang, 1789) & 6 & 1 & 0 & 0 & D1 P1 H3 A2 \\
\hline Melitaea athalia (Rott., 1775) & 7 & 1 & 2 & 0 & D1 P3 H2 A3 \\
\hline Limentis populi (L., 1758) & 2 & 0 & 0 & 0 & D1 P1 H2 A2 \\
\hline Limentis camilla (L., 1764) & 6 & 1 & 0 & 0 & D1 P1 H2 A2 \\
\hline Apatura iris (L., 1764) & 1 & 0 & 1 & 0 & D1 P1 H2 A2 \\
\hline Pararge aegeria (L., 1758) & 8 & 3 & 1 & 0 & D2 P2 H2 A1 \\
\hline Lasiommata megera (L., 1767) & 7 & 3 & 3 & 0 & D2 P2 H2 A1 \\
\hline Coenonympha arcania (L., 1761) & 8 & 3 & 5 & 0 & D1 P3 H2 A3 \\
\hline Coenonympha pamphilus (L., 1758) & 8 & 3 & 8 & 7 & D1 P3 H2 A1 \\
\hline Pyronia tithonus (L., 1771) & 8 & 3 & 9 & 8 & D1 P2 H1 A3 \\
\hline Aphantopus hyperantus (L., 1758) & 8 & 3 & 8 & 7 & D1 P3 H2 A2 \\
\hline Maniola jurtina (L., 1758) & 8 & 3 & 9 & 9 & D2 P3 H4 A1 \\
\hline Erebia medusa ([Den. \& Schiff.], 1775) & 7 & 0 & 0 & 0 & D1 P3 H2 A2 \\
\hline Melanargia galathea (L., 1758) & 8 & 2 & 9 & 8 & D1 P2 H2 A1 \\
\hline Species number & 59 & 52 & 43 & 38 & \\
\hline
\end{tabular}



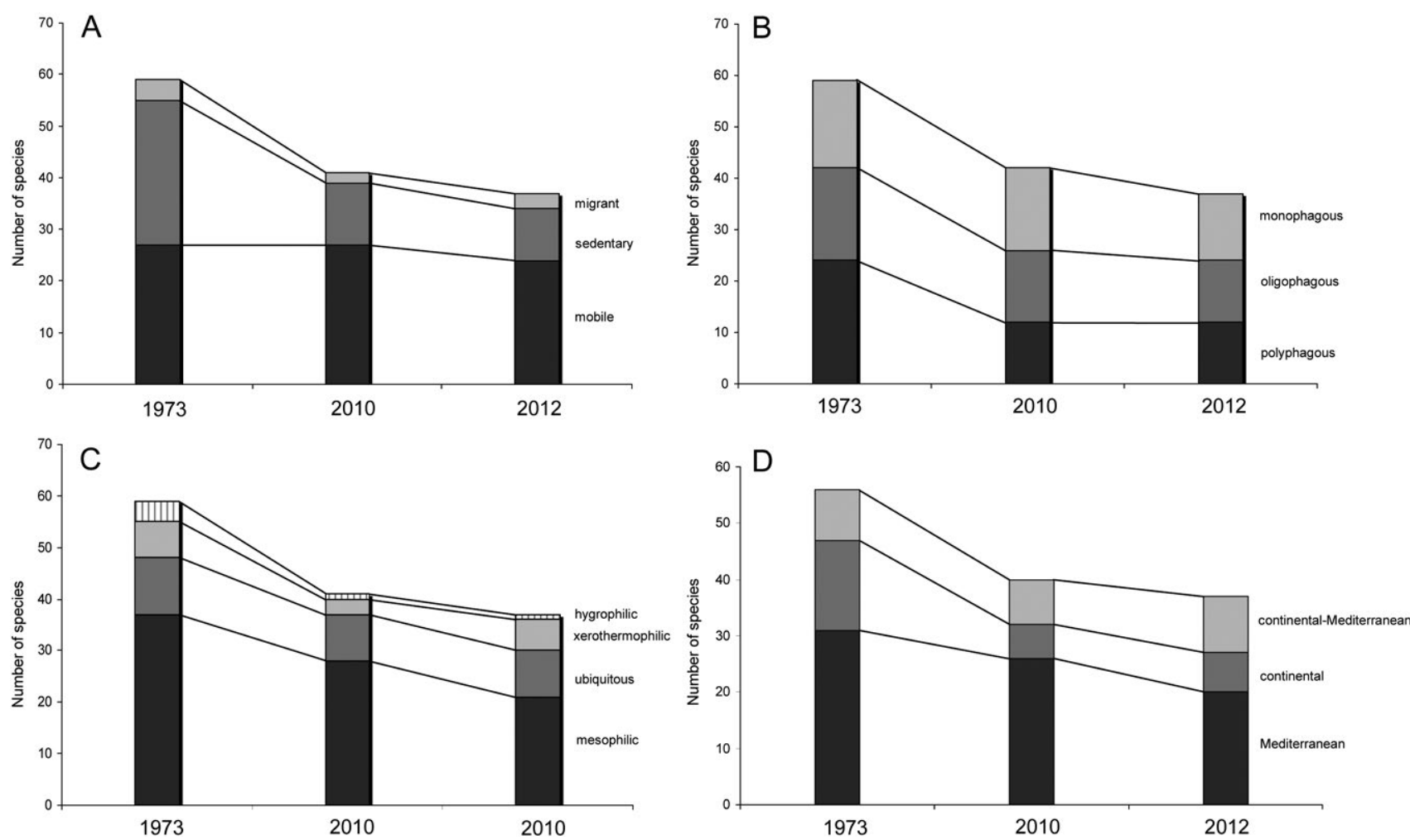

Fig. 3. Changes in the composition of the butterfly community between years in terms of the functional traits studied: A - dispersal, B - larval food plant specialisation, $\mathrm{C}$ - habitat requirements and $\mathrm{D}$ - global distribution patterns.

abilities declined by $64 \%$, whereas there were only moderate decline rates in the numbers of mobile and migrant species. Moreover, the decreases in the numbers of hydrophilic and mesophilic species exceeded those recorded for xerothermophilic and ubiquitous species. The numbers of moist-habitat species, in particular, declined dramatically by $75 \%$. Numbers of monophagous species decreased more than that of polyphagous and oligophagous species. Hence, half of the species of butterfly with highly host specific larvae recorded in 1973 were not detected in 2010 and 2012.

Analyses of the affiliation of the newly recorded species to particular functional groups produced no clear results. All the functional groups are represented among the newly observed species in 2010/12 with the majority being mobile and xerothermophilic.

\section{Community temperature index}

We found a slight but significant increase in CTI-values between 1973 and 2012 (Kruskal-Wallis-Anova, $p_{\text {same }}<$ 0.05 ), which is associated with a proportional increase in thermophilic species within butterfly communities (Fig. 4). In parallel, annual mean temperature increased from $9.2^{\circ} \mathrm{C}$ to $10^{\circ} \mathrm{C}$ over the period of the study. However, the standard deviation of CTI-values decreased remarkably. Since 1970, the temperature in the Trier region increased but there were considerable annual fluctuations in temperature [German Weather Service (DWD)]. There was no temporal trend in the temperature recorded over the

TABLE 2. Summary of CTI-values and standard deviations for each butterfly community monitored between 1973 and 2012 . CTIvalues are calculated based on the numbers of species recorded along each transect in each year of the study.

\begin{tabular}{lcccc}
\hline Transect & 1973 & 1986 & 2010 & 2012 \\
\hline Tiergarten I & $8.933( \pm 0.824)$ & - & $9.049( \pm 0.770)$ & $9.169( \pm 0.875)$ \\
Tiergarten II & $8.789( \pm 0.940)$ & $9.188( \pm 0.833)$ & $9.037( \pm 0.812)$ & $9.065( \pm 0.739)$ \\
Tiergarten III & $8.945( \pm 0.869)$ & - & $9.001( \pm 0.782)$ & $9.000( \pm 0.684)$ \\
Hill & $8.880( \pm 0.872)$ & $9.054( \pm 0.725)$ & $9.015( \pm 0.723)$ & $9.284( \pm 0.881)$ \\
Kernscheid & $8.916( \pm 0.828)$ & - & $9.047( \pm 0.739)$ & $9.052( \pm 0.776)$ \\
Brettenbach I & $8.912( \pm 0.787)$ & - & $8.979( \pm 0.759)$ & $9.090( \pm 0.766)$ \\
Brettenbach II & $8.868( \pm 0.710)$ & - & $9.054( \pm 0.773)$ & $9.208( \pm 0.719)$ \\
Avelertal II & - & - & $9.030( \pm 0.736)$ & $9.004( \pm 0.789)$ \\
Avelertal III & $8.972( \pm 0.856)$ & $8.998( \pm 0.833)$ & $8.928( \pm 0.721)$ & $9.151( \pm 0.817)$ \\
\hline Total & $8.904( \pm 0.952)$ & $9.069( \pm 0.833)$ & $9.013( \pm 0.707)$ & $9.108( \pm 0.781)$ \\
\hline
\end{tabular}




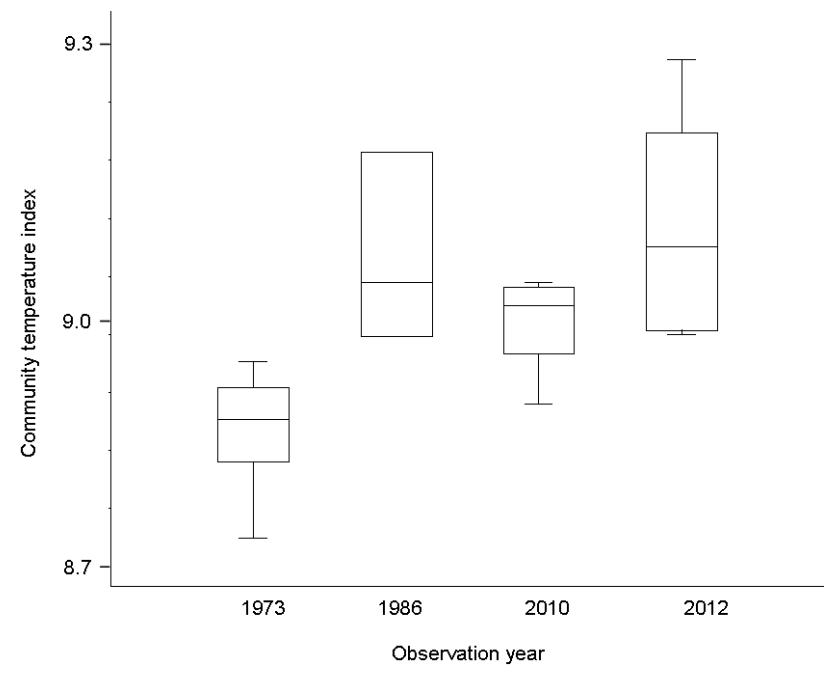

Fig. 4. Range of community temperature indices mirroring the proportion of heat and cold loving species recorded in each year of the study. The calculation was based on the number of species recorded along each transect, respectively. CTI-values for 1986 are based on only three fallows and thus lack representativeness.

period of this study. Neither the changes in annual temperatures or trend in the climate over time were accurately reflected in the CTI-values (Fig. 5). A summary of all CTI-values and their corresponding standard deviations for each butterfly community monitored between 1973 and 2012 is given in Table 2.

\section{DISCUSSION}

Butterfly diversity declined dramatically in the region of Trier between 1973 and 2012. These results are similar to the declines reported for Britain, Belgium, Switzerland and the Czech Republic (Lepidopterologen-Arbeitsgruppe, 1987; Benes \& Kuras, 1998; Maes \& Van Dyck, 2001; Thomas et al., 2004b, Kadlec et al., 2008) and apparently are part of the trans-European loss of biodiversity. The decline in species was most pronounced for those that are host or habitat specific, i.e. there was a smaller decline in the diversity of habitat generalists than habitat specialists.

Open grasslands are habitats with relatively warm microclimates (Dennis, 1993). During a period of climate warming the expectation is that the diversity of thermophilic species, often originating from Mediterranean regions, should increase. It is also likely that increasing habitat temperatures are unlikely to favour hygrophilic and cold-adapted species. There has been a slight upward trend in the CTI-values since the 1970s, which reflects a proportional increase in heat-loving species in butterfly communities. However, the increase in CTI-values does not match the trend in climate. We did not find a correlation between CTI-values and the annual mean temperature or between the CTI and the moving temperature average of a particular year and that of the previous year, which appeared plausible especially for univoltine butterfly species (Wiemers et al., 2012). Although a complete match of annual mean temperatures and CTI-values might not be expected due to latitude-dependent differences in land-sea distribution across Europe, our results

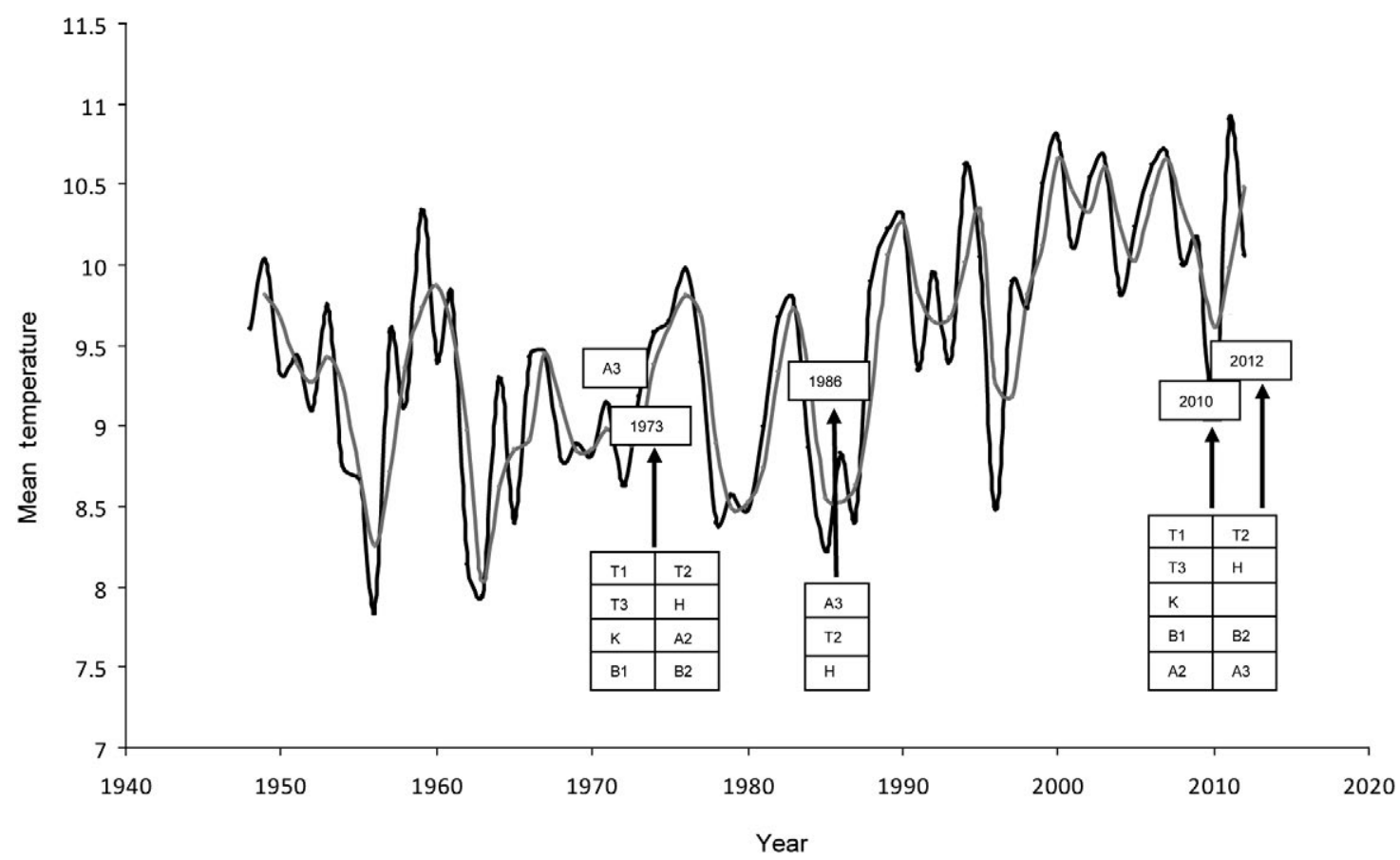

Fig. 5. Variability in mean temperature recorded from 1948-2012 in the study region. The black line indicates the annual mean temperature measured at Trier Petrisberg, the grey line the two-year moving average temperature. Calculated CTI-values for the transects in each of the years studied do not match the relevant average temperatures of the series or that of the previous year nor the general temperature increase (T1 - Tiergarten I, T2 - Tiergarten II, T3 - Tiergarten III, H - Hill, K - Kernscheid, B1 - Brettenbach I, B2 - Brettenbach II, A2 - Avelertal II, A3 - Avelertal III). 
indicate a considerable reduction in both, warm and cold adapted species in the region studied, which is also reflected in a reduction in the standard deviation of the CTI-values. Although the decrease in the number of coldhabitat dwellers was more pronounced in our study area, the numbers of species favoured by high temperatures also declined dramatically. Our results indicate that both of these functional groups are unable to cope with temperature changes. Hence, changes in climate at the macroand micro-scales both seem to adversely affect equally thermophilic and cold-adapted species resulting in a severe loss of species belonging to both of these functional groups.

At the macro-scale, local distributions of species can be explained in terms of their thermal environments (Gillingham et al., 2012). Species at the margins of their distributions are known to be very sensitive to environmental disturbances (Parmesan et al., 1999; Oliver et al., 2009). Therefore, these taxa might be strongly affected by a change in climate especially if it involves an increase in the extreme temperatures. We assume that an increase in winter temperatures and in the variability in the temperature during the cold season can result in a marked decline in the number of cold-adapted species in the region studied. Hence, conditions that have recently transgressed their climatic tolerances might account for the observed local extinctions of species belonging to this functional group.

At the micro-scale, vegetation and structure of a habitat (e.g. short turf, immature soil, hedge structures) are often correlated with micro-climatic variations and seem to play a major role in determining the occurrence of particular species. There is a large body of evidence that indicates that variations in the height of vegetation and its density generate major differences in microclimate (Schneider \& Eugster, 2005; Suggitt et al., 2011). For open habitats, Thomas (1983) demonstrated that the surface temperature of short turf can be about $8^{\circ} \mathrm{C}$ higher than that of tall grass turf. Due to increasing eutrophication, the growth capacities of plants have been greatly enhanced (Bartolmess et al., 2011), especially when combined with an increase in temperature and precipitation. Increase in biomass possibly causes a marked deterioration in the microclimatic conditions close to the ground. Currently, microclimatic cooling might not be outweighed by large-scale global warming. Consequently, conditions for the development of the larvae of thermophilic species might decrease in the short term, preventing successful reproduction and thus maybe even the occurrence of these species in the area. This also might account for the paradoxical situation of warm-loving species becoming rarer in a warming environment.

In addition to changes in micro-climatic conditions, the effect of nitrogen on open habitats might also cause small-scale changes in vegetation patterns as it favours nitrophyts (e.g. Rubus sp., Cirsium arvense, Cirsium vulgare) at the cost of other plants. Many open habitats have suffered a reduction in plant diversity and hence a loss of nectar and larval food plants, which is especially serious for habitat specialists (Van Swaay, 2002). Hence, the dramatic decline in monophagous species might be the result of substantial changes in vegetation composition over time resulting from agricultural abandonment and eutrophication.

Ecosystem engineers like grazing mammals are expected to positively influence plant diversity, regulate vegetation growth and increase structural heterogeneity in open habitats as many conservation programs involve mowing and grazing (Römermann et al., 2009; Drobnik et al., 2011). However, additional nutritional import in the form of faeces might favour nitrophilic plant species. As a result of trampling there are likely to be smaller populations in grazed habitats, and this in combination with habitat fragmentation could have resulted in an increase in the loss of species (Bogich et al., 2011). We found neither positive nor additional negative effects of grazing on butterfly communities in our study. Grazing effects in the study area differed considerably from year to year due to variation in the intensity, timing and duration, as the vegetation was able to recover if there were long intervals between grazing. We presume that environmental factors like slope, insolation and geological conditions had a marked effect on vegetation as there was no significant difference in species richness or species composition of grazed and non grazed patches (Mann-Whitney-Test $\mathrm{p}>$ 0.05). Consequently, contrary to Settele et al. (2009) in our case a compensation of habitat degradation by grazing seems unlikely.

A decrease in habitat quality necessarily affects species with low dispersal capacities. As shown by Filz et al. (2013), the connectivity between semi-natural grasslands is frequently insufficient to facilitate emigration or habitat shifts. In agricultural landscapes, distances between suitable habitats continuously increase, frequently exceeding dispersal capacities of butterflies (Ouin et al., 2004). As a result of the reduced accessibility of non-adjacent patches, populations are restricted to small fragments of habitat that are particularly vulnerable to micro-habitat changes (Thomas, 2000; Dover \& Settele, 2009).

The ongoing decline in species induced by severe changes in habitat quality will consequently result in an entire rearrangement of trait diversity in butterflies in south-western Germany (c.f. Kadlec et al., 2009). Our results indicate that there are several factors associated with climate and habitat changes driving this rearrangement, which are difficult to distinguish and likely to operate in combination. Both factors seem to affect butterfly diversity at different scales partly in opposing directions (Warren et al., 2001). Generally, functional groups mirroring high habitat specialisation are locally at high risk of extinction and being replaced by ubiquists. However, most of these functional groups have been identified as particularly important for species conservation purposes (Henle et al., 2004). Hence, our results not only indicate there has been a depletion in trait diversity in butterfly communities, but also point the way to a more trait-based approach in species conservation. 
ACKNOWLEDGEMENTS. The first author was funded by the Friedrich Ebert Foundation and the Ministry for Environment, Agriculture, Viticulture, Food and Forests Rhineland-Palatinate. We acknowledge the Struktur- und Genehmigungsdirektion Nord (Koblenz) for permission to survey butterflies in the Trier region. We thank O. Schweiger for calculating the STI values. We thank two anonymous referees and M. Konvicka for additional useful comments on the manuscript.

\section{REFERENCES}

Bartholmess H., Schlottmann K. \& Nobel W. 2011: Immission masurements with diffusive samplers and lichen mappings to show the impact of nitrogen in the environment and its effects. - Gefahrst. Reinhalt. Luft 71: 165-172.

Beaumont L.J., Pitman A., Perkins S., Zimmermann N.E., Yoccoz N.G. \& Thuiller W. 2011: Impacts of climate change on the world's most exceptional ecoregions. - Proc. Natl. Acad. Sci. USA 108: 2306-2311.

Benes J. \& KuRAS T. 1998: Long term diversity changes of butterflies and burnets of the Opavska pahorkatina Hills and Nizky Jesenik Mts. (Czech Republic) III. - Cas. Slezsk. Muz. Opava 47: 245-270.

BINK F.A. 1992: Ecologische Atlas van de Dagvlinders van Noordwest-Europa. Schuyt, Haarlem, 512 pp.

Bogich T.L., Barker G.M., Mahlfeld K., Climo F., Green R. \& BALMFORD A. 2011: Fragmentation, grazing, and the speciesarea relationship. - Ecography 35: 224-231.

Dawson T.P., Jackson S.T., House J.I., Prentice I.C. \& Mace G.M. 2011: Beyond predictions: Biodiversity conservation in a changing climate. - Science 332: 53-58.

DenNIS R.L.H. 1993: Butterflies and Climate Change. Manchester University Press, Manchester, 302 pp.

Devictor V., Van Swaay C., Brereton T., Brotons L., Chamberlain D., Heliölä J., Herrando S., Julliard R., Kuussaari M., Lindström Å., Reif J., Roy D.B., Schweiger O., Settele J., Stefanescu C., Van Strien A., Van Turnhout C., Vermouzek Z., WallisDeVries M., Wynhoff I. \& Jiguet F. 2012: Differences in the climatic debts of birds and butterflies at a continental scale. - Nature Climate Change 2: 121-124.

Dover J. \& Settele J. 2009: The influences of landscape structure on butterfly distribution and movement: a review. $-J$. Insect Conserv. 13: 3-27.

Drobnik J., Römermann C., Bernhardt-Römermann M. \& Poschlod P. 2011: Adaptation of plant functional group composition to management changes in calcareous grassland. Agr. Ecosyst. Environ. 145: 29-37.

Ebert G. \& Rennwald E. (eds) 1991: Die Schmetterlinge Baden-Württembergs. Band 1 und 2. Eugen Ulmer, Stuttgart, $552+535 \mathrm{pp}$.

Filz K.J., Engler J.O., Stoffels J., Weitzel M. \& Schmitt T. 2013: Missing the target? A critical view on butterfly conservation efforts on calcareous grasslands in south western Germany. - Biodivers. Conserv. DOI 10.1007/s10531-0120413-0.

Gaedicke R. \& Heinicke W. (eds) 1999: Verzeichnis der Schmetterlinge Deutschlands (Entomofauna Germanica 3). Entomol. Nachr. Ber. (Dresden) 5: 1-216.

GASTON K.J. \& Fuller R.A. 2007: Biodiversity and extinction: losing the common and the widespread. - Prog. Phys. Geogr. 31: 213-225.

German Weather Service: URL: www.dwd.de, accessed 14.ii.2013.

Gillette D.P., Fortner A.M., Franssen N.R., Cartwright S., Tobler C.M., Wesner J.S., Reneau P.C., Reneau F.H., Schlupp I., Marsh-Matthews E.C., Matthews W.J.,
Broughton R.E. \& Lee C.W. 2012: Patterns of change over time in darter (Teleostei: Percidae) assemblages of the Arkansas River basin, northeastern Oklahoma, USA. Ecography 35: 588-864.

Gillingham P.K., Palmer S.C.F., Huntley B., Kunin W.E., Chipperfield J.D. \& Thomas C.D. 2012: The relative importance of climate and habitat in determining the distributions of species at different spatial scales: a case study with ground beetles in Great Britain. - Ecography 35: 831-838.

Henle K., Lindenmayer D.B., Margules C.R., Saunders D.A. \& Wissel C. 2004: Species survival in fragmented landscapes: where are we now? - Biodivers. Conserv. 13: 1-8.

Kadlec T., Benes J., Jarosik V. \& Konvicka M. 2008: Revisiting urban refuges: Changes of butterfly and burnet fauna in Prague reserves over three decades. - Landsc. Urban Plan 85: $1-11$.

Kadlec T., Kotela M.A., Novák I., Konvicka M. \& Jarosik V. 2009: Effect of land use and climate on the diversity of moth guilds with different habitat specialization. - Commun. Ecol. 10: $152-158$.

KudRnA O. 2002: The distribution atlas of European butterflies. -Oedippus 20: 1-342.

Kudrna O., Harpke A., Lux K., Pennerstorfer J., Schweiger O., Settele J. \& Wiemers M. 2011: The Distribution Atlas of European Butterflies. Gesellschaft für Schmetterlingsschutz e.V., Halle, 576 pp.

LEPIDOPTEROLOGEN-ARBEITSGRUPPE (eds) 1987: Tagfalter und ihre Lebensräume. Arten - Gefährdung - Schutz. Schweiz und angrenzende Gebiete. Band 1. Schweizerischer Bund für Naturschutz, $516 \mathrm{pp}$.

León-Cortés J.L., Cowley M.J.R. \& Thomas C.D. 2000: The distribution and decline of a widespread butterfly Lycaena phlaeas in a pastoral landscape. - Ecol. Entomol. 25: 285-294.

Maes D. \& VAN Dyck H. 2001: Butterfly diversity loss in Flanders (north Belgium): Europe's worst case scenario? - Biol. Conserv. 99: 263-276.

Oliver T., Hill J.K., Thomas C.D., Brereton T. \& Roy D.B. 2009: Changes in habitat specificity of species at their climatic range boundaries. - Ecol. Let. 12: 1091-1102.

Mantyka-Pringle C.S., Martin T.G. \& Rhodes J.R. 2012: Interactions between climate and habitat loss effects on biodiversity: a systematic review and meta-analysis. - Glob. Change Biol. 18: 1239-1252.

Ouin A., Aviron S., Dover J. \& Burel F. 2004: Complementation / supplementation of resources for butterflies in agricultural landscapes. - Agr. Ecosyst. Environ. 103: 473-479.

Parmesan C., Ryrholm N., Stefanescu C., Hill J.K., Thomas C.D., Descimon H., Huntley B., Kaila L., Kullberg J., Tammaru T., Tennent W.J., Thomas J.A. \& Warren M. 1999: Poleward shifts in geographical ranges of butterfly species associated with regional warming. - Nature 399: 579-583.

POllard E. \& YATES T.J. 1993: Monitoring Butterflies for Ecology and Conservation. The British Butterfly Monitoring Scheme. Chapman \& Hall, London, 292 pp.

RÁkosy L. \& SchmitT T. 2011: Are butterflies and moths suitable ecological indicator systems for restoration measures of semi-natural calcareous grassland habitats? - Ecol. Ind. 11: 1040-1045.

ReInHARDT R. \& Thust R. 1988: Zur ökologische Klassifizierung und zum Gefährdungsgrad der Tagfalter der DDR. Entomol. Nachr. Ber. 32: 199-206.

Römermann C., Bernhardt-Römermann M., Kleyer M. \& Poschlod P. 2009: Substitutes for grazing in semi-natural grasslands - do mowing or mulching represent valuable alter- 
natives to maintain vegetation structure? $-J$. Veg. Sci. 20 : 1086-1098.

Sala O.E., Chapin F.S. III, Armesto J.J., Berlow R., Bloomfield J., Dirzo R., Huber-Sanwald E., Huenneke L.F., Jackson R.B., Kinzig A., Leemans R., Lodge D., Mooney H.A., Oesterheld M., Poff N.L., Sykes M.T., Walker B.H., WALKER M. \& WALL D.H. 2000: Global biodiversity scenarios for the year 2100. - Science 287: 1770-1774.

Settele J., Feldmann R. \& Reinhardt R. 1999: Die Tagfalter Deutschlands-Ein Handbuch für Freilandökologen, Umweltplaner und Naturschützer. Ulmer, Stuttgart, $452 \mathrm{pp}$.

Settele J., Kudrna O., Harpke A., Kühn I., Van Swaay C., Verovinik R., Warren M., Wiemers M., Hanspach J., Hickler T., Kühn E., Van Halder I., Veling K., Vliegenthart A., Wynhoff I. \& Schweiger O. 2008: Climatic Risk Atlas of European Butterflies. Biorisk (Sofia \& Moscow) (Suppl.) 1: $1-710$.

Settele J., Dover J., Dolek M. \& Konvicka M. 2009: Butterflies of European ecosystems: impact of land use and options for conservation management. In Settele J., Shreeve J., Konvicka M. \& Van Dyck H. (eds): Ecology of Butterflies in Europe. Cambridge University Press, Cambridge, pp. 353-370.

SchmitT T. \& RÁkosy L. 2007: Changes of traditional agrarian landscape and their conservation implications: a case study of butterflies in Romania. - Divers. Distrib. 13: 855-862.

SCHNeIDER N. \& Eugster W. 2005: Historical land use changes and mesoscale summer climate on the Swiss Plateau. $-J$. Geophys. Res. 110: D19102.

Suggitt A.J., Gillingham P.K., Hill J.K., Huntley B., Kunin W. E., Roy D.B. \& Thomas C.D. 2011: Habitat microclimates drive fine-scale variation in extreme temperatures. - Oikos 120: $1-8$.

Thомаs J.A. 1983: The ecology and conservation of Lysandra bellargus (Lepidoptera, Lycaenidea) in Britain. - J. Appl. Ecol. 20: $59-83$.

Thомаs C.D. 2000: Dispersal and extinction in fragmented landscapes. - Proc. R. Soc. Lond. (B) 267: 139-145.

Thomas C.D., Cameron A., Green R.E., Bakkenes M., Beaumont L.J., Collingham Y.C., Erasmus B.F.N., de Siqueira M.F., Grainger A., Hannah L., Hughes L., Huntley B., van
JaArsveld A.S., Midgley G.F., Miles L., Ortega-Huerta M.A., Townsend Peterson A., Phillips O.L. \& Williams S.E. 2004a: Extinction risk from climate change. - Nature 427: $145-148$.

Thomas J.A., Telfer M.G., Roy D.B., Preston C.D., Greenwood J.J.D., Asher J., Fox R., Clarke R.T. \& Lawton J.H. 2004b: Comparative losses of British butterflies, birds and plants and global extinction crisis. - Science 303: 1879-1881.

VAN SWAay C.A.M. 2002: The importance of calcareous grasslands for butterflies in Europe. - Biol. Conserv. 104: 315-318.

Van Swayy C.A.M., Nowicki P., Settele J. \& Van Strien A.J. 2008: Butterfly monitoring in Europe: methods, applications and perspectives. - Biodiv. Conserv. 17: 3455-3469.

Van Swahy C., Maes D., Collins S., Munguira M.L., Šašić M., Settele J., Verovinik R., Warren M., Wiemers M., Wynhoff I. \& Cuttelod A. 2011: Applying IUCN criteria to invertebrates: How red is the Red List of European butterflies? Biol. Conserv. 144: 470-478.

WARREN M.S. 1997: Conserving Lepidoptera in a changing environment: a perspective from Western Europe. - J. Insect Conserv. 1: i-iv.

Warren M.S., Hill J.K., Thomas J.A., Asher J., Fox R., Huntley B., Roy D.B., Telfer M.G., Jeffcoate S., Harding P., Jeffcoate G., Willis S.G., Greatorex-Davies J.N., Moss D. \& Thомаs C.D. 2001: Rapid responses of British butterflies to opposing forces of climate and habitat change. Nature 414: 65-91.

Wenzel M., Schmitt T., Weitzel M. \& Seitz A. 2006: The severe decline of butterflies on western calcareous grasslands during the last 30 years: A conservation problem. - Biol. Conserv. 128: 542-552.

Wiemers M., Denner M., Schweiger O. \& Winter M. 2012: Biodiversitätsindikatoren für Klimaveränderungen am Beispiel der Tagfalter und Libellen Sachsens. In Korn H., Feit U. \& Schliep R. (eds): Biodiversität und Klima - Vernetzung der Akteure in Deutschland VIII - Ergebnisse und Dokumentation des 8. Workshops. - BfN-Skripten 307: 54-57.

Received March 20, 2013; revised and accepted May 2, 2013

APPENDIX 1. Turnover rates calculated in order to identify differences between the communities recorded along the different transects due to spatial autocorrelation. Transects were classified with regard to their spatial distance from each other (T1 - Tiergarten I, T2 - Tiergarten II, T3 - Tiergarten III, H - Hill, K - Kernscheid, B1 - Brettenbach I, B2 - Brettenbach II, A2 - Avelertal II, A3 Avelertal III).

\begin{tabular}{|c|c|c|c|c|c|c|c|}
\hline \multicolumn{2}{|c|}{$<1 \mathrm{~km}$} & \multicolumn{2}{|c|}{$1-2 \mathrm{~km}$} & \multicolumn{2}{|c|}{$2-3 \mathrm{~km}$} & \multicolumn{2}{|c|}{$>3 \mathrm{~km}$} \\
\hline Transects & Turnover & Transects & Turnover & Transects & Turnover & Transects & Turnover \\
\hline $\mathrm{A} 2 / \mathrm{A} 3$ & 0.1935 & $\mathrm{~B} 1 / \mathrm{H}$ & 0.3696 & $\mathrm{~A} 2 / \mathrm{B} 1$ & 0.2222 & $\mathrm{~A} 2 / \mathrm{H}$ & 0.3750 \\
\hline B1/B2 & 0.2340 & $\mathrm{~B} 1 / \mathrm{T} 1$ & 0.1852 & $\mathrm{~A} 2 / \mathrm{B} 2$ & 0.3673 & A $2 / \mathrm{K}$ & 0.2857 \\
\hline H/T3 & 0.4419 & $\mathrm{~B} 1 / \mathrm{T} 2$ & 0.2830 & $\mathrm{~A} 3 / \mathrm{B} 1$ & 0.1667 & $\mathrm{~A} 2 / \mathrm{T} 1$ & 0.2143 \\
\hline $\mathrm{T} 1 / \mathrm{T} 2$ & 0.2182 & $\mathrm{~B} 1 / \mathrm{T} 3$ & 0.2245 & $\mathrm{~A} 3 / \mathrm{B} 2$ & 0.2727 & $\mathrm{~A} 2 / \mathrm{T} 2$ & 0.3091 \\
\hline \multirow[t]{10}{*}{$\mathrm{T} 2 / \mathrm{T} 3$} & 0.2000 & B2/H & 0.3415 & $\mathrm{~B} 1 / \mathrm{K}$ & 0.2592 & $\mathrm{~A} 2 / \mathrm{T} 3$ & 0.2941 \\
\hline & & $\mathrm{B} 2 / \mathrm{T} 1$ & 0.2653 & $\mathrm{~B} 2 / \mathrm{K}$ & 0.2653 & $\mathrm{~A} 3 / \mathrm{H}$ & 0.3148 \\
\hline & & $\mathrm{B} 2 / \mathrm{T} 2$ & 0.3333 & $\mathrm{~K} / \mathrm{T} 1$ & 0.1786 & $\mathrm{~A} 3 / \mathrm{K}$ & 0.2258 \\
\hline & & $\mathrm{B} 2 / \mathrm{T} 3$ & 0.1818 & & & $\mathrm{~A} 3 / \mathrm{T} 1$ & 0.1613 \\
\hline & & $\mathrm{H} / \mathrm{K}$ & 0.4167 & & & $\mathrm{~A} 3 / \mathrm{T} 2$ & 0.2131 \\
\hline & & $\mathrm{H} / \mathrm{T} 1$ & 0.3125 & & & $\mathrm{~A} 3 / \mathrm{T} 3$ & 0.2281 \\
\hline & & $\mathrm{H} / \mathrm{T} 2$ & 0.4894 & & & & \\
\hline & & $\mathrm{K} / \mathrm{T} 2$ & 0.2000 & & & & \\
\hline & & $\mathrm{K} / \mathrm{T} 3$ & 0.1765 & & & & \\
\hline & & $\mathrm{T} 1 / \mathrm{T} 3$ & 0.1373 & & & & \\
\hline
\end{tabular}

